\title{
REVIEW
}

\section{Venous oxygen saturation as a physiologic transfusion trigger}

\author{
Benoit Vallet*, Emmanuel Robin and Gilles Lebuffe \\ This article is one of ten reviews selected from the Yearbook of Intensive Care and Emergency Medicine 2010 (Springer Verlag) and co-published \\ as a series in Critical Care. Other articles in the series can be found online at http://ccforum/series/yearbook. Further information about the \\ Yearbook of Intensive Care and Emergency Medicine is available from http://www.springer.com/series/2855.
}

\section{Introduction}

Venous oxygen saturation is a clinical tool which integrates the whole body oxygen uptake-to-delivery $\left(\mathrm{VO}_{2}-\right.$ $\mathrm{DO}_{2}$ ) relationship. In the clinical setting, in the absence of pulmonary artery catheter (PAC)-derived mixed venous oxygen saturation $\left(\mathrm{SvO}_{2}\right)$, the central venous oxygen saturation $\left(\mathrm{ScvO}_{2}\right)$ is increasingly being used as a reasonably accurate surrogate [1]. Central venous catheters (CVCs) are simpler to insert, and generally safer and cheaper than PACs. The CVC allows sampling of blood for measurement of $\mathrm{ScvO}_{2}$ or even continuous monitoring if an oximetry catheter is being used. The normal range for $\mathrm{SvO}_{2}$ is 68 to $77 \%$ and $\mathrm{ScvO}_{2}$ is considered to be $5 \%$ above these values [2].

A decrease in hemoglobin $(\mathrm{Hb}, \mathrm{g} / \mathrm{dl})$ is likely to be associated with a decrease in $\mathrm{DO}_{2}$ when cardiac output (CO) remains unchanged, since $\mathrm{DO}_{2}=\mathrm{CO} \times \mathrm{CaO}_{2}$, where $\mathrm{CaO}_{2}$ is arterial oxygen content and is $\approx \mathrm{Hb} \times \mathrm{SaO}_{2} \times 1.34$ (where $\mathrm{SaO}_{2}$ is the arterial oxygen saturation in\%; and 1.34 is the oxygen-carrying capacity of $\mathrm{Hb}^{\text {in }} \mathrm{mlO}_{2} / \mathrm{g} \mathrm{Hb}$ ), when one ignores the negligible oxygen not bound to $\mathrm{Hb}$ [1]. A decrease in $\mathrm{Hb}$ is one of the four determinants responsible for a decrease in $\mathrm{SvO}_{2}\left(\right.$ or $\mathrm{ScvO}_{2}$ ), alone or in combination with hypoxemia (decrease in $\mathrm{SaO}_{2}$ ), an increase in $\mathrm{VO}_{2}$ without a concomitant increase in $\mathrm{DO}_{2}$, or a fall in cardiac output.

When $\mathrm{DO}_{2}$ decreases, $\mathrm{VO}_{2}$ is maintained (at least initially) by an increase in oxygen extraction $\left(\mathrm{O}_{2} \mathrm{ER}\right)$ since $\mathrm{O}_{2} \mathrm{ER}=\mathrm{VO}_{2} / \mathrm{DO}_{2} . \mathrm{As} \mathrm{VO}_{2} \approx\left(\mathrm{SaO}_{2}-\mathrm{SvO}_{2}\right) \times(\mathrm{Hb} \times 1.34 \times$ $\mathrm{CO}$ ) and $\mathrm{DO}_{2} \approx \mathrm{SaO}_{2} \times \mathrm{Hb} \times 1.34 \times \mathrm{CO}, \mathrm{O}_{2} \mathrm{ER}$ and $\mathrm{SvO}_{2}$ are thus linked by a simple equation: $\mathrm{O}_{2} \mathrm{ER} \approx\left(\mathrm{SaO}_{2}-\right.$

*Correspondence: bvallet@chru-lille.fr

Department of Anesthesiology and Intensive Care Medicine, University Hospital of Lille, Rue Michel Polonovski, 59037 Lille, France
$\left.\mathrm{SvO}_{2}\right) / \mathrm{SaO}_{2}$ or even simpler: $\mathrm{O}_{2} \mathrm{ER} \approx 1-\mathrm{SvO}_{2}$. Assuming $\mathrm{SaO}_{2}=1$ [3], if $\mathrm{SvO}_{2}$ is $40 \%$, then $\mathrm{O}_{2} \mathrm{ER}$ is $60 \%$.

Because it integrates $\mathrm{Hb}$, cardiac output, $\mathrm{VO}_{2}$ and $\mathrm{SaO}_{2}$, the venous oxygen saturation therefore helps to assess the $\mathrm{VO}_{2}-\mathrm{DO}_{2}$ relationship and tolerance to anemia during blood loss.

\section{Venous oxygen saturation as a physiologic transfusion trigger}

When $\mathrm{DO}_{2}$ decreases beyond a certain threshold, it induces a decrease in $\mathrm{VO}_{2}$. This point is known as the critical $\mathrm{DO}_{2}\left(\mathrm{DO}_{2}\right.$ crit), below which there is a state of $\mathrm{VO}_{2}-\mathrm{DO}_{2}$ dependency also called tissue dysoxia. In humans, dysoxia is usually present when $\mathrm{SvO}_{2}$ falls below a critical $40-50 \%\left(\mathrm{SvO}_{2}\right.$ crit); this may, however, also occur at higher levels of $\mathrm{SvO}_{2}$ when $\mathrm{O}_{2}$ ER is impaired. Usually efforts in correcting cardiac output (by fluids or inotropes), and/or $\mathrm{Hb}$ and/or $\mathrm{SaO}_{2}$ and/or $\mathrm{VO}_{2}$ must target a return of $\mathrm{SvO}_{2}\left(\mathrm{ScvO}_{2}\right)$ from 50 to $65-70 \%$ [4]. In sedated critically ill patients in whom life support was discontinued, the $\mathrm{DO}_{2}$ crit was found to be approximately 3.8 to $4.5 \mathrm{mlO}_{2} / \mathrm{kg} / \mathrm{min}$ for a $\mathrm{VO}_{2}$ of about $2.4 \mathrm{mlO}_{2} / \mathrm{g} /$ min; $\mathrm{O}_{2}$ ER reached an $\mathrm{O}_{2}$ ERcrit of $60 \%$ [5] with $\mathrm{SvO}_{2}$ crit being $\approx 40 \%$.

In a landmark study by Rivers et al. [6], patients admitted to an emergency department with severe sepsis and septic shock were randomized to standard therapy (aiming for a central venous pressure [CVP] of $8-12 \mathrm{mmHg}$, mean arterial pressure (MAP) $\geq 65 \mathrm{mmHg}$, and urine output $\geq 0.5 \mathrm{ml} / \mathrm{kg} / \mathrm{h}$ ) or to early goal-directed therapy where, in addition to the previous parameters, an $\mathrm{ScvO}_{2}$ of at least $70 \%$ was targeted by optimizing fluid administration, keeping hematocrit $\geq 30 \%$, and/or giving dobutamine to a maximum of $20 \mu \mathrm{g} / \mathrm{kg} / \mathrm{min}$. The initial $\mathrm{ScvO}_{2}$ in both groups was low (49 $\pm 12 \%$ ), suggesting a hypodynamic condition before resuscitation was started. 
From the $1^{\text {st }}$ to the $7^{\text {th }}$ hour, the amount of fluid received was significantly larger in the early goal-directed therapy patients $(\approx 5,000 \mathrm{ml}$ vs $3,500 \mathrm{ml}, \mathrm{p}<0.001)$, fewer patients in the early goal-directed therapy group received vasopressors (27.4 vs $30.3 \%, \mathrm{p}=\mathrm{NS}$ ), and significantly more patients were treated with dobutamine (13.7 vs $0.8 \%$, $\mathrm{p}<0.001)$. It is noticeable that the number of patients receiving red blood cells (RBCs) was significantly larger in the early goal-directed therapy group than in the control group (64.1 vs $18.5 \%$ ) suggesting that the strategy of targeting a $\mathrm{ScvO}_{2}$ of at least $70 \%$ was associated with more decisions to transfuse once fluid, vasopressors, and dobutamine had been titrated to improve tissue oxygenation. In the follow-up period between the $7^{\text {th }}$ and the $72^{\text {nd }}$ hour, mean $\mathrm{ScvO}_{2}$ was higher, mean arterial $\mathrm{pH}$ was higher, and plasma lactate levels and base excess were lower in patients who received early goal-directed therapy. Organ failure score and mortality were significantly different in patients receiving standard therapy compared to early goal-directed therapy patients. This was the first study to demonstrate that initiation of early goal-directed therapy to achieve an adequate level of tissue oxygenation by $\mathrm{DO}_{2}$ (as judged by $\mathrm{ScvO}_{2}$ monitoring) could significantly reduce mortality.

In a prospective observational study [7], we tested how well the $\mathrm{ScvO}_{2}$ corresponded to the French recommendations for blood transfusion and to the anesthesiologist's decision to transfuse. The French recommendations for blood transfusion were presented during a consensus conference organized in 2003 by the French Society of Intensive Care Medicine (Société de Réanimation de Langue Française, SRLF) [8]. These recommendations are based on plasma $\mathrm{Hb}$ concentration and associated clinical state (Table 1), and apart from in cardiac and septic patients, the threshold $\mathrm{Hb}$ value for blood transfusion is $7 \mathrm{~g} / \mathrm{dl}$. Sixty high risk surgical patients in whom the need for a blood transfusion was discussed postoperatively were included in the study [7]. They were eligible for study inclusion if they were hemodynamically stable and equipped with a CVC. The decision to transfuse was taken by the anesthesiologist in charge of the patient. The anesthesiologist was aware of the SRLF recommendations; if requested, he/she was provided with the $\mathrm{ScvO}_{2}$ value that was obtained at the same time as the blood was sampled for the Hb concentration. The following parameters were registered: Age, a history of cardiovascular disease, presence of sepsis, number of blood units transfused, agreement with the SRLF recommendations. A decision to transfuse was made in 53 of the 60 general and urologic surgical patients. $\mathrm{ScvO}_{2}$ and $\mathrm{Hb}$ were measured before and after blood transfusion, together with hemodynamic parameters (heart rate, systolic arterial pressure). Patients were retrospectively divided into two groups according to the $\mathrm{ScvO}_{2}$ before
Table 1. The French recommendations for blood transfusion in critically ill patients are based on a recent consensus by the French Society of Intensive Care Medicine (Société de Réanimation de Langue Française; SRLF) using threshold values for hemoglobin (Hb) together with the clinical context to indicate blood transfusion [8].

\begin{tabular}{ll}
\hline Threshold value of $\mathbf{H b}(\mathbf{g} / \mathbf{d l})$ & Clinical context \\
\hline 10 & - Acute coronary syndrome \\
9 & - Ischemic heart disease \\
& $\cdot$ Stable heart failure \\
8 & $\cdot$ Age $>75$ \\
7 & Severe sepsis \\
\hline
\end{tabular}

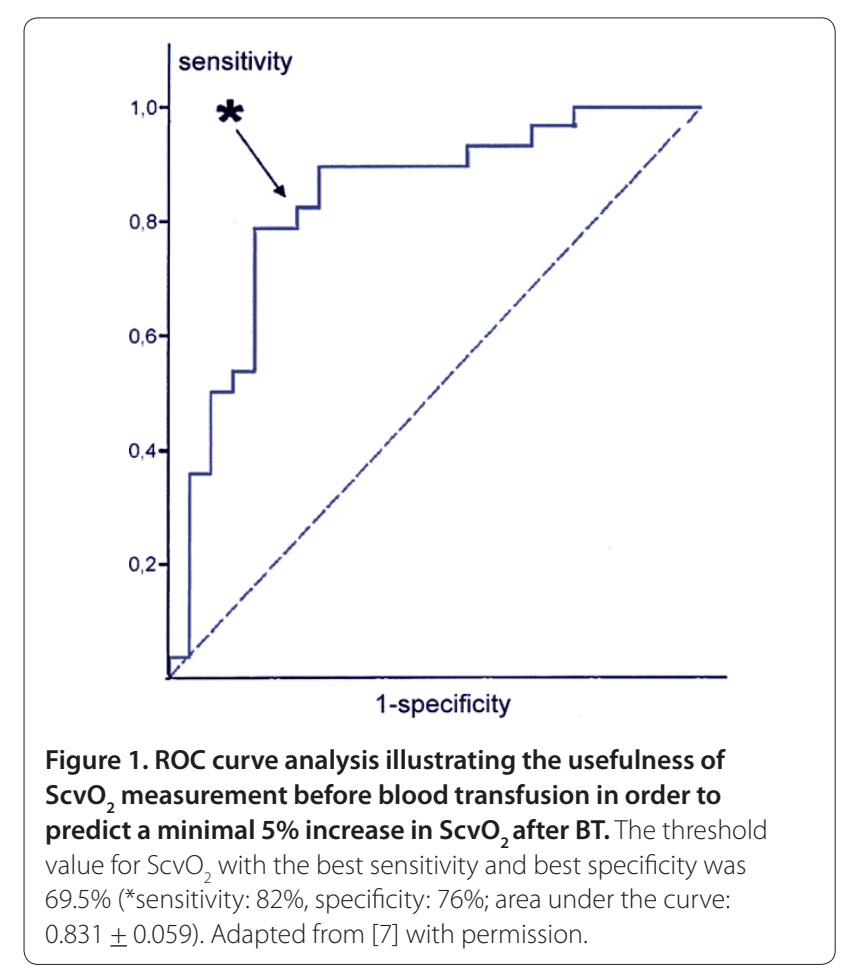

blood transfusion (< or $\geq 70 \%$ ); each of these groups was further divided into two groups according to agreement or not with the SRLF recommendations for blood transfusion. The $\mathrm{ScvO}_{2}$ threshold value of $69.5 \%$ (sensitivity $82 \%$; specificity $76 \%$ ) was validated with a receiver operator characteristic (ROC) curve analysis (Figure 1).

Overall, demographic characteristics were similar (age, weight, number of blood units transfused) among the groups. Blood transfusion provided a significant and approximately similar increase in hemoglobin concentration for all patients in the four groups but the $\mathrm{ScvO}_{2}$ value increased significantly only in patients with $\mathrm{ScvO}_{2}$ $<70 \%$ before blood transfusion (Figure 2 and Table 2). 


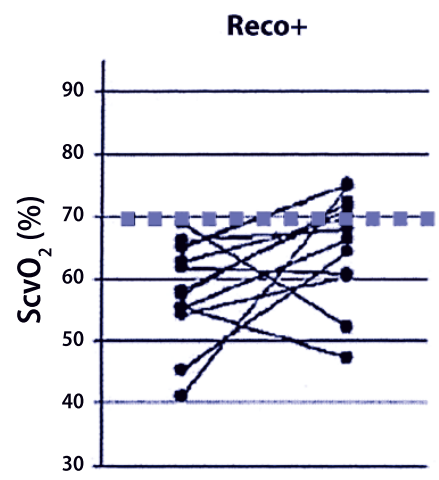

Before-After BT

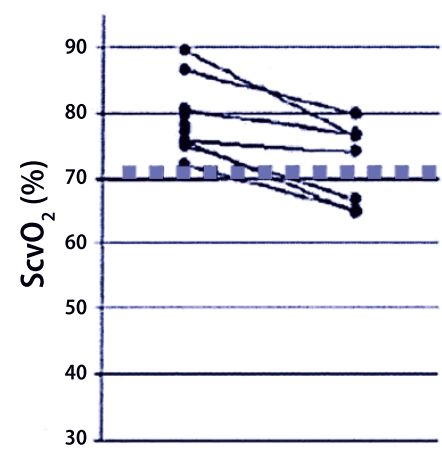

Before-After BT
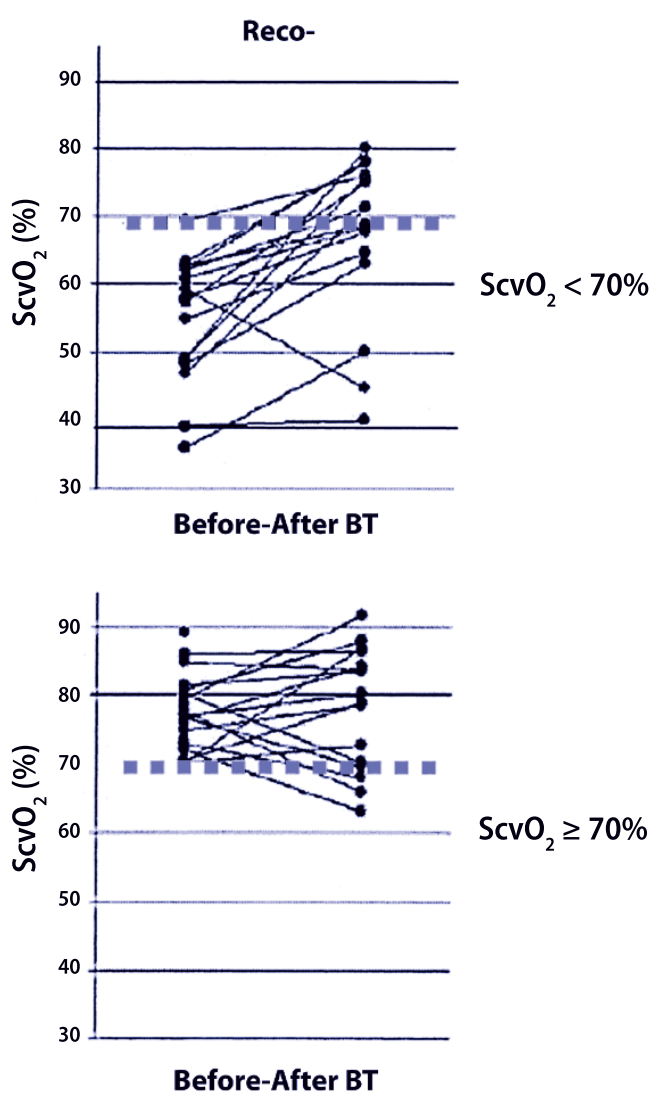

Figure 2. Individual evolutions in $\mathrm{ScvO}_{2}$ before and after blood transfusion (BT) according to agreement (Reco+) or not (Reco-) with the SRLF recommendations for transfusion and according to the $\mathrm{ScvO}_{2}$ before transfusion (< or $\left.\geq 70 \%\right)$. Adapted from [7] with permission.

Table 2. Central venous $\mathrm{O}_{2}$ saturation $\left(\mathrm{ScvO}_{2}\right)$, hemoglobin $(\mathrm{Hb})$, heart rate $(\mathrm{HR})$ and systolic arterial pressure (SAP) values (median [ $\mathrm{Cl}$ 95\%]) in 53 hemodynamically stable postoperative patients who received blood transfusion (BT), divided into two groups according to their $\mathrm{ScvO}_{2}$ before blood transfusion (< or $\geq 70 \%$ ); and then into four groups according to agreement or not with the SRLF recommendations for transfusion.

\begin{tabular}{|c|c|c|c|c|c|}
\hline \multirow{2}{*}{$\begin{array}{l}\text { SRLF } \\
\text { recommendations }\end{array}$} & \multicolumn{2}{|c|}{$\mathrm{ScvO}_{2}<70 \%$} & \multicolumn{2}{|c|}{$\mathrm{ScvO}_{2} \geq 70 \%$} & \multirow{2}{*}{$\begin{array}{l}\text { Kruskal-Wallis } \\
\text { test }(p<.05)\end{array}$} \\
\hline & Yes $(n=15)$ & No $(n=13)$ & Yes $(n=18)$ & No $(n=7)$ & \\
\hline $\mathrm{ScvO}_{2}$ preBT & $57.4[48.2-62.0]$ & $58.0[55.3-65.0]$ & $76.9[72.0-80.8]$ & $75.7[75.0-86.4]$ & $p<0.001$ \\
\hline $\mathrm{ScvO}_{2}$ postBT & $68.7^{*}[63.0-75.6]$ & $67.8^{*}[60.7-72.0]$ & 78.7 [70.0-84.2] & $74,0^{*}[65.0-76.7]$ & $p<0.01$ \\
\hline $\mathrm{Hb}$ preBT & $7.4[7.1-7.9]$ & 7.8 [7.4-8.7] & 7.5 [7.3-8.1] & 8.1 [7.5-8.2] & Ns \\
\hline $\mathrm{Hb}$ postBT & $9.4^{* *}[8.7-9.7]$ & $10.0^{* *}[9.4-10.6]$ & $10.1^{* *}[9.3-10.6]$ & $9.8^{*}[9.4-10.7]$ & Ns \\
\hline HR preBT & 88 [78-90] & 96 [93-120] & 92 [85-105] & 95 [81-112] & Ns \\
\hline HR postBT & 92 [84-97] & 95 [89-100] & 89 [78-104] & 96 [78-100] & Ns \\
\hline SAP preBT & 118 [101-141] & 130 [120-150] & 128 [114-150] & 130 [124-151] & Ns \\
\hline SAP postBT & 133 [119-140] & $120[106-140]$ & $141^{*}[128-161]$ & $140 *[133-175]$ & $p=0.047$ \\
\hline
\end{tabular}

Ns: non-significant; ${ }^{*} \mathrm{p}<0.05 ;{ }^{* *} \mathrm{p}<0.01$; Wilcoxon test for values before (preBT) vs after transfusion (postBT). Adapted from [7]

The heart rate and systolic arterial pressure did not help in the decision to transfuse.

The conclusions of this observational study were as follows: 1$)$ Twenty of the 53 patients (37.7\%) received a blood transfusion against SRLF recommendations; 2) thirteen of these 20 patients (65\%) had an $\mathrm{ScvO}_{2}<70 \%$ and nevertheless seemed to benefit from the blood transfusion (according to the $\mathrm{VO}_{2} / \mathrm{DO}_{2}$ relationship), and one may speculate that the fact that they did not comply with the SRLF recommendations for blood transfusion could have contributed to a "lack of blood transfusion" in these patients; indeed, according to the $\mathrm{ScvO}_{2}$ (which 
remained largely below 70\%) blood transfusion may even have been insufficient ( $\mathrm{n}=2$ blood units) in this subgroup; 4) $54.5 \%$ of the patients (18/33) met the SRLF recommendation had an $\mathrm{ScvO}_{2} \geq 70 \%$ and received a blood transfusion although $\mathrm{VO}_{2} / \mathrm{DO}_{2}$ may have been adequate; one may speculate that transfusion in these patients could have contributed to an "excess of blood transfusion".

Following the study by Rivers et al. [6] and our own observations [7] we can conclude that $\mathrm{ScvO}_{2}$ appears to be an interesting parameter to help with transfusion decisions in hemodynamically unstable patients with severe sepsis or in stable high-risk surgical patients equipped with a CVC. $\mathrm{ScvO}_{2}$ can be proposed as a simple and universal physiologic transfusion trigger. This suggestion merits a controlled randomized study in which patients would be separated into two treatment groups: 1) A control group in which the decision to transfuse would be made according to $\mathrm{Hb}$ threshold values (similar to those presented by the SRLF); 2) an $\mathrm{ScvO}_{2}$ goaldirected group in which the decision to transfuse would be made according to an $\mathrm{ScvO}_{2}$ value $<70 \%$ as soon as the $\mathrm{Hb}$ value was less than $10 \mathrm{~g} / \mathrm{dl}$ (hematocrit < 30\%) providing that the CVP was 8 to $12 \mathrm{mmHg}$.

\section{The concept of physiologic transfusion trigger}

In an 84-year-old male Jehovah's Witness undergoing profound hemodilution, the $\mathrm{DO}_{2}$ crit was $4.9 \mathrm{mlO}_{2} / \mathrm{kg} /$ min for a $\mathrm{VO}_{2}$ of about $2.4 \mathrm{mlO}_{2} / \mathrm{kg} / \mathrm{min}$; the $\mathrm{Hb}$ value at the $\mathrm{DO}_{2}$ crit was $3.9 \mathrm{~g} / \mathrm{dl}$ [9]. This $\mathrm{Hb}$ value can be defined as the critical $\mathrm{Hb}$ value. Consistent with these results, in young, healthy, and conscious (which means higher $\mathrm{VO}_{2}$ ) volunteers undergoing acute hemodilution with $5 \%$ albumin and autologous plasma, $\mathrm{DO}_{2}$ crit was found to be less than $7.3 \mathrm{mlO}_{2} / \mathrm{kg} / \mathrm{min}$ for a $\mathrm{VO}_{2}$ of $3.4 \mathrm{mlO}_{2} / \mathrm{kg} / \mathrm{min}$ [10] and an $\mathrm{Hb}$ value of $4.8 \mathrm{~g} / \mathrm{dl}$. The same investigators studied healthy resting humans to test whether acute isovolemic reduction of blood hemoglobin concentration to $5 \mathrm{~g} / \mathrm{dl}$ would produce an imbalance in myocardial oxygen supply and demand, resulting in myocardial ischemia [11]. Heart rate increased from $63 \pm 11$ (baseline measured before hemodilution began) to $94 \pm 14$ beats/ min (a mean increase of $51 \pm 27 \%$; $<0.0001$ ), whereas MAP decreased from $87 \pm 10$ to $76 \pm 11 \mathrm{mmHg}$ (a mean decrease of $12 \pm 13 \%$; $<0.0001$ ), mean diastolic blood pressure decreased from $67 \pm 10$ to $56 \pm 10 \mathrm{mmHg}$ (a mean decrease of $15 \pm 16 \%$; $<<0.0001$ ), and mean systolic blood pressure decreased from $131 \pm 15$ to $121 \pm 16 \mathrm{mmHg}$ (a mean decrease of $7 \pm 11 \% ; \mathrm{p}=0.0001$ ). Electrocardiographic (EKG) changes were monitored continuously using a Holter EKG recorder for detection of myocardial ischemia. During hemodilution, transient, reversible ST-segment depression developed in three asymptomatic subjects at hemoglobin concentrations of
$5 \mathrm{~g} / \mathrm{dl}$. The subjects who had EKG ST-segment changes had significantly higher maximum heart rates (110 to 140 beats/min) than those without EKG changes, despite having similar baseline values. The higher heart rates that developed during hemodilution may have contributed to the development of an imbalance between myocardial oxygen supply and demand resulting in EKG evidence of myocardial ischemia. An approach to the myocardial oxygen balance is offered by the product systolic arterial pressure $\times$ heart rate which should remain below 12,000. For heart rate $=110$ beats $/ \mathrm{min}$, if systolic arterial pressure is $120 \mathrm{mmHg}$, systolic arterial pressure $\times$ heart rate $=13,200$ and may be considered too high for the myocardial $\mathrm{VO}_{2}$.

In 20 patients older than 65 years and free from known cardiovascular disease, $\mathrm{Hb}$ was decreased from $11.6 \pm 0.4$ to $8.8 \pm 0.3 \mathrm{~g} / \mathrm{dl}$ [12]. With stable filling pressures, cardiac output increased from $2.02 \pm 0.11$ to $2.19 \pm 0.10 \mathrm{l} / \mathrm{min} / \mathrm{m}^{2}$ $(\mathrm{p}<0.05)$ while systemic vascular resistance (SVR) decreased from $1796 \pm 136$ to $1568 \pm 126$ dynes $/ \mathrm{s} / \mathrm{cm}^{5}$ $(\mathrm{p}<0.05)$ and $\mathrm{O}_{2} E R$ increased from $28.0 \pm 0.9$ to $33.0 \pm 0.8 \%$ $(\mathrm{p}<0.05)$ resulting in stable $\mathrm{VO}_{2}$ during hemodilution. While no alterations in ST segments were observed in lead II, ST segment deviation became slightly less negative in lead $V_{5}$ during hemodilution, from $-0.03 \pm 0.01$ to $-0.02 \pm 0.01 \mathrm{mV}(\mathrm{p}<0.05)$. The authors concluded that isovolemic hemodilution to a hemoglobin value of about $8.8 \mathrm{~g} / \mathrm{dl}$ was the limit that could be tolerated in these patients [12].

In 60 patients with coronary artery disease receiving chronic beta-adrenergic blocker treatment and scheduled for coronary artery bypass graft (CABG) surgery, Hb was decreased from $12.6 \pm 0.2$ to $9.9 \pm 0.2 \mathrm{~g} / \mathrm{dl}(\mathrm{p}<0.05)$ [13]. With stable filling pressures, cardiac output increased from $2.05 \pm 0.05$ to $2.27 \pm 0.05 \mathrm{l} / \mathrm{min} / \mathrm{m}^{2}(\mathrm{p}<0.05)$ and $\mathrm{O}_{2}$ ER from $27.4 \pm 0.6$ to $31.2 \pm 0.7 \%(\mathrm{p}<0.05)$, resulting in stable $\mathrm{VO}_{2}$. No alterations in $\mathrm{ST}$ segments were observed in leads II and $\mathrm{V}_{5}$ during hemodilution. Individual increases in cardiac index and $\mathrm{O}_{2} \mathrm{ER}$ were not linearly related to age or left ventricular ejection fraction [13].

Healthy young volunteers were also tested with verbal memory and standard computerized neuropsychologic tests before and twice after acute isovolemic reduction of their $\mathrm{Hb}$ concentration to $5.7 \pm 0.3 \mathrm{~g} / \mathrm{dl}$ [14]. Heart rate, MAP, and self-assessed sense of energy were recorded at the time of each test. Reaction time for Digit-Symbol Substitution Test (DSST) increased, delayed memory was degraded, MAP and energy level decreased, and heart rate increased (all $\mathrm{p}<0.05$ ). Increasing $\mathrm{PaO}_{2}$ to $406 \pm 47 \mathrm{mmHg}$ reversed the DSST result and the delayed memory changes to values not different from those at the baseline $\mathrm{Hb}$ concentration of $12.7 \pm 1.0 \mathrm{~g} / \mathrm{dl}$, and decreased heart rate $(\mathrm{p}<0.05)$ although MAP and energy level changes were not altered with increased $\mathrm{PaO}_{2}$ during acute anemia. In that study, the authors confirmed that acute isovolemic 
anemia subtly slows human reaction time, degrades memory, increases heart rate, and decreases energy levels [14].

Subsequent studies identified the cause of the observed cognitive function deficits in impaired central processing as quantified by measurement of the P300 latency. The P300 response was significantly prolonged when unmedicated healthy volunteers were hemodiluted from hemoglobin concentrations of $12.4 \pm 1.3$ to $5.1 \pm 0.2 \mathrm{~g} / \mathrm{dl}$ [15]. The increased P300 latencies could be reversed to values not significantly different from baseline when inspired oxygen concentration was increased from 21 (room air) to $100 \%$. These results suggest that P300 latency is a variable that is sensitive enough to predict subtle changes in cognitive function. Accordingly, increase in the P300 latency above a certain threshold may serve as a monitor of inadequate cerebral oxygenation and as an organ-specific transfusion trigger in the future. Spahn and Madjdpour recently commented [16] that Weiskopf et al. [15, 17] have opened a "window to the brain" with respect to monitoring the adequacy of cerebral oxygenation during acute anemia.

These observations and results clearly indicate that there is no 'universal' $\mathrm{Hb}$ threshold that could serve as a reliable transfusion trigger and that transfusion guidelines should take into account the patient's individual ability to tolerate and to compensate for the acute decrease in $\mathrm{Hb}$ concentration. Useful transfusion triggers should rather consider signs of inadequate tissue oxygenation that may occur at various hemoglobin concentrations depending on the patient's underlying disease(s) [18].

\section{Conclusion}

Physiologic transfusion triggers should progressively replace arbitrary Hb-based transfusion triggers [19]. The same conclusions were drawn by Orlov et al. in a recent trial using a global oxygenation parameter for guiding $\mathrm{RBC}$ transfusion in cardiac surgery [20]. The use of goaldirected erythrocyte transfusions should render the management of allogeneic red cell use more efficient and should help: 1) in saving blood and avoiding unwanted adverse effects; and 2) in promoting and optimizing the adequacy of this life-saving treatment [16]. These 'physiologic' transfusion triggers can be based on signs and symptoms of impaired global (lactate, $\mathrm{SvO}_{2}$ or $\mathrm{ScvO}_{2}$ ) or, even better, regional tissue (EKG ST-segment, DSST or P300 latency) oxygenation; they do, however, have to include two important simple hemodynamic targets: heart rate and MAP or systolic arterial pressure.

\section{Abbreviations}

$\mathrm{BT}=$ blood transfusion, $\mathrm{CO}=$ cardiac output, $\mathrm{CVC}=$ central venous catheter, $\mathrm{CVP}=$ central venous pressure, $\mathrm{EKG}=$ electrocardiographic, $\mathrm{Hb}=$ hemoglobin, $\mathrm{O}_{2} \mathrm{ER}=$ oxygen extraction, $\mathrm{MAP}=$ mean arterial pressure, $\mathrm{PAC}=$ pulmonary artery catheter, $\mathrm{RBC}=$ red blood cell, $\mathrm{ROC}=$ receiver operator characteristic, $\mathrm{SaO}_{2}=$ arterial oxygen saturation, $\mathrm{ScvO}_{2}=$ central venous oxygen saturation, $\mathrm{SvO}_{2}=$ mixed venous oxygen saturation, $\mathrm{VO}_{2}-\mathrm{DO}_{2}=$ whole body oxygen uptake-to-delivery.

\section{Competing interests}

BV is a consultant for Edwards Lifesciences. ER and GL declare that they have no competing interests.

\section{Published: 9 March 2010}

\section{References}

1. Dueck MH, Klimek M, Appenrodt S, Weigand C, Boerner U: Trends but not individual values of central venous oxygen saturation agree with mixed venous oxygen saturation during varying hemodynamic conditions. Anesthesiology 2005, 103:249-257.

2. Reinhart K, Kuhn HJ, Hartog C, Bredle DL: Continuous central venous and pulmonary artery oxygen saturation monitoring in the critically ill. Intensive Care Med 2004, 30:1572-1578.

3. Räsänen J: Mixed venous oximetry may detect critical oxygen delivery. Anesth Analg 1990, 71:567-568.

4. Vallet B, Singer M: Hypotension. In Patient-Centred Acute Care Training, First Edition. Edited by Ramsay G. European Society of Intensive Care Medicine, Brussels, 2006.

5. Ronco JJ, Fenwick JC, Tweeddale MG, et al:: Identification of the critical oxygen delivery for anaerobic metabolism in critically ill septic and nonseptic humans. JAMA 1993, 270:1724-1730

6. Rivers E, Nguyen B, Havstad S, et al:: Early goal-directed therapy in the treatment of severe sepsis and septic shock. N Engl J Med 2001, 345:1368-1377.

7. Adamczyk S, Robin E, Barreau O, et al:: [Contribution of central venous oxygen saturation in postoperative blood transfusion decision]. Ann Fr Anesth Reanim 2009, 28:522-530.

8. Conférence de consensus (2003) Société de réanimation de langue française - XXIII Conférence de consensus en réanimation et en médecine d'urgence - jeudi 23 octobre 2003: Transfusion érythrocytaire en réanimation (nouveau-né exclu). Réanimation 2003, 12:531-537.

9. van Woerkens EC, Trouwborst A, van Lanschot JJ: Profound hemodilution: what is the critical level of hemodilution at which oxygen deliverydependent oxygen consumption starts in an anesthetized human? Anesth Analg 1992, 75:818-821.

10. Lieberman JA, Weiskopf RB, Kelley SD, et al:: Critical oxygen delivery in conscious humans is less than $7.3 \mathrm{mLO}_{2} \cdot \mathrm{kg}^{-1} \cdot \mathrm{min}^{-1}$. Anesthesiology 2000, 92:407-413.

11. Leung JM, Weiskopf RB, Feiner J, et al.: Electrocardiographic ST-segment changes dur ing acute, severe isovolemic hemodilution in humans. Anesthesiology 2000, 93:1004-1010.

12. Spahn DR, Zollinger A, Schlumpf RB, et al:: Hemodilution tolerance in elderly patients without known cardiac disease. Anesth Analg 1996, 82:681-686.

13. Spahn DR, Schmid ER, Seifert B, Pasch T: Hemodilution tolerance in patients with coronary artery disease who are receiving chronic beta-adrenergic blocker therapy Anesth Analg 1996, 82:687-694.

14. Weiskopf RB, Feiner J, Hopf HW, et al:: Oxygen reverses deficits of cognitive function and memory and increased heart rate induced by acute severe isovolemic anemia. Anesthesiology 2002, 96:871-877.

15. Weiskopf RB, Toy P, Hopf HW, et al:: Acute isovolemic anemia impairs central processing as determined by P300 latency. Clin Neurophysio/ 2005, 116:1028-1032.

16. Spahn DR, Madjdpour C: Physiologic transfusion triggers: do we have to use (our) brain? Anesthesiology 2006, 104:905-906.

17. Weiskopf RB, Feiner J, Hopf H, et al.: Fresh blood and aged stored blood are equally efficacious in immediately reversing anemia-induced brain oxygenation deficits in humans. Anesthesiology 2006, 104:911-920.

18. Madjdpour C, Spahn DR, Weiskopf RB: Anemia and perioperative red blood cell transfusion: a matter of tolerance. Crit Care Med 2006, 34:S102-108.

19. Vallet B, Adamczyk S, Barreau O, Lebuffe G: Physiologic transfusion triggers. Best Pract Res Clin Anaesthesio/ 2007, 21:173-181.

20. Orlov D, O'Farrell R, McCluskey SA, et al.: The clinical utility of an index of global oxygenation for guiding red blood cell transfusion in cardiac surgery. Transfusion 2009, 49:682-688.

doi:10.1186/cc8851

Cite this article as: Vallet $B$, et al.: Venous oxygen saturation as a physiologic transfusion trigger. Critical Care 2010, 14:213. 